\title{
Systematic review of growth factors and cytokines for the management of oral mucositis in cancer patients and clinical practice guidelines
}

\author{
Richard M. Logan ${ }^{1}$ - Abdul Rahman Al-Azri ${ }^{1,2}$ • Paolo Bossi ${ }^{3} \cdot$ Andrea M. Stringer $^{4,5}$ • Jamie K. Joy ${ }^{6}$ Yoshihiko Soga ${ }^{7}$. \\ Vinisha Ranna ${ }^{8}$. Anusha Vaddi ${ }^{9,10}$ • Judith E. Raber-Durlacher ${ }^{11,12} \cdot$ Rajesh V. Lalla ${ }^{10} \cdot$ Karis Kin Fong Cheng $^{13}$. \\ Sharon Elad ${ }^{9}$ - On behalf of the Mucositis Study Group of the Multinational Association of Supportive Care in Cancer/ \\ International Society of Oral Oncology (MASCC/ISOO)
}

Received: 29 September 2019 / Accepted: 5 November 2019 / Published online: 21 February 2020

(C) Springer-Verlag GmbH Germany, part of Springer Nature 2020

\begin{abstract}
Purpose To update the clinical practice guidelines for the use of growth factors and cytokines for the prevention and/or treatment of oral mucositis (OM).

Methods A systematic review was conducted by the Mucositis Study Group of the Multinational Association of Supportive Care in Cancer/International Society of Oral Oncology (MASCC/ISOO). The body of evidence for each intervention, in each cancer treatment setting, was assigned an evidence level. The findings were added to the database used to develop the $2014 \mathrm{MASCC} /$ ISOO clinical practice guidelines. Based on the evidence level, the following guidelines were determined: recommendation, suggestion, and no guideline possible.

Results A total of 15 new papers were identified within the scope of this section and were merged with 51 papers that were reviewed in the previous guidelines update. Of these, 14, 5, 13, 2, and 1 were randomized controlled trials about KGF-1, G-CSF, GM-CSF, EGF, and erythropoietin, respectively. For the remaining agents there were no new RCTs. The previous recommendation for intravenous KGF-1 in patients undergoing autologous hematopoietic stem cell transplantation (HSCT) conditioned with high-dose chemotherapy and TBI-based regimens is confirmed. The previous suggestion against the use of topical GM-CSF for the prevention of OM in the setting of high-dose chemotherapy followed by autologous or allogeneic stem cell transplantation remains unchanged.

Conclusions Of the growth factors and cytokines studied for the management of OM, the evidence supports a recommendation in favor of KGF-1 and a suggestion against GM-CSF in certain clinical settings.
\end{abstract}

Keywords Oral mucositis · Growth factors $\cdot$ Cytokines $\cdot$ Systematic review $\cdot$ Guidelines

Abdul Rahman Al-Azri

abdulrahman.alazri@moh.gov.om

Richard M. Logan

richard.logan@adelaide.edu.au

Paolo Bossi

paolo.bossi@unibs.it

Andrea M. Stringer

andrea.stringer@unisa.edu.au

Jamie K. Joy

jamie.joy@ctca-hope.com

Yoshihiko Soga

y.soga@okayama-u.ac.jp

\author{
Vinisha Ranna \\ Vinisha.Ranna@mountsinai.org \\ Anusha Vaddi \\ anushareddy999@gmail.com \\ Judith E. Raber-Durlacher \\ j.raber.durlacher@acta.nl \\ Rajesh V. Lalla \\ Lalla@uchc.edu \\ Karis Kin Fong Cheng \\ Kares_cheng@nuhs.edu.sg \\ Sharon Elad \\ SElad@URMC.Rochester.edu
}

Extended author information available on the last page of the article 


\section{Introduction}

Oral mucositis $(\mathrm{OM})$ remains a dose-limiting toxicity of cancer therapy, including chemotherapy (CT), radiotherapy (RT), radiochemotherapy (RT-CT), and HSCT. In addition to impairment of oral functions, severe OM can cause treatment interruptions and significant complications necessitating hospitalization, the use of narcotic analgesics, or additional nutritional support. These in turn may adversely affect overall cancer therapy outcomes and patients' quality of life. In addition, OM substantially increases the cost associated with cancer therapy [19].

Various agents have been investigated with respect to effectiveness in prevention or treatment of OM. As part of the continuous work of the Mucositis Study Group (MSG) of the Multinational Association of Supportive Care in Cancer/ International Society of Oral Oncology (MASCC/ISOO), clinical trials of therapeutic interventions are periodically reviewed to identify new agents and provide new evidence into the published clinical practice guidelines for the management of mucositis [45].

Growth factors (GF) are proteins that stimulate cell growth, proliferation, and differentiation, while cytokines are proteins or glycoproteins that modulate inflammatory and immune responses. Evidence supports an important role played by proinflammatory cytokines in the pathogenesis of OM [49]. The 2013 MASCC/ISOO clinical practice guidelines for mucositis management recommended the use of palifermin, a human recombinant keratinocyte growth factor (KGF-1) to prevent $\mathrm{OM}$ in patients receiving high dose $\mathrm{CT}$ or total body irradiation (TBI) followed by autologous HSCT for hematological malignancies and a suggestion was made against the use of granulocyte macrophage colony-stimulating factor (GMCSF) mouthwash for the prevention of OM in the setting of high-dose chemotherapy followed by autologous or allogeneic HSCT [66]. No guideline was possible for any other GF or cytokine due to inconclusive evidence [66]. This paper describes the findings of the most recent systematic review conducted by MSG regarding GF and cytokines for the management of OM in cancer patients and the update of the MASCC/ ISOO clinical practice guidelines on this topic.

\section{Methods}

The methods are described in detail in Ranna et al. [67]. Briefly, a search for relevant papers indexed in the literature from January 1, 2011 to June 30, 2016 was conducted using Pubmed/Web of Science/EMBASE, with papers selected for review based on defined inclusion and exclusion criteria.

Publications were reviewed by two independent reviewers, and data were extracted using a standard electronic form. Studies were scored for their level of evidence (LoE) based on Somerfield criteria [80], and flaws were listed according to Hadorn criteria [26]. A well-designed study was defined as a study with no major flaws per the Hadorn criteria.

Findings from reviewed studies were merged with the evidence from the previous MASCC/ISOO guideline update. Findings from the reviewed studies were integrated into guidelines based on the overall $\mathrm{LoE}$ for each intervention. Guidelines were classified into three types: recommendation, suggestion, and no guideline possible.

Guidelines were specified based on the following variables: (1) aim of the intervention (prevention or treatment of OM), (2) treatment modality (RT, CT, RT-CT, or high dose conditioning therapy for HSCT), and (3) route of administration of the intervention.

The list of intervention keywords used for the literature search of the growth factors and cytokines section is presented in the Methods paper [67].

\section{Results}

A total of 1091 papers were identified in the literature search: 684 from PubMed and 407 from Web of Science. After assessment of the abstracts, 1065 articles were excluded due to repetition across databases, non-clinical studies, meta-analyses, and reviews. One paper was transferred from another section of the guidelines update. Twenty-seven papers were retrieved for final review. After review of these full papers, five were transferred to other relevant sections in MSG according to the type of intervention (see list of sections in the Methods paper [67]). In addition, five papers were excluded as they did not satisfy the inclusion criteria (i.e. not related to mucositis). Ultimately, fifteen papers are included in this report and merged with fifty-one papers from the previous guidelines update. Additionally, thirteen papers that were reviewed in the previous guidelines update about interventions for which there is no new evidence are listed in this current guidene update.

\section{KGF}

Keratinocyte growth factors (KGF) are members of the fibroblast growth factor (FGF) superfamily [49]. Palifermin has pleiotropic activity [20]. It is believed to support the mucosal barrier integrity through its mitogenic activity on epithelial and endothelial cells, fibroblasts, and keratinocytes. KGF-1, also known as FGF-7, is involved in a number of cell survival activities [81]. This includes the suppression of apoptosis and activation of a redox-sensitive transcription factor, nerve growth factor-2 (Nrf2) that coordinates the expression of cytoprotective genes in keratinocytes, fibroblasts, and endothelial cells. Palifermin also upregulates interleukin-13 which 
attenuates the effects of tumor necrosis factor (TNF) [81]. KGF may also downregulate other pro-inflammatory cytokines that are involved in the pathobiology of mucositis [49]. Two other members of the KGF family included in this review, FGF-20 (velafermin) and human recombinant KGF-2 (repifermin), have overlapping activity with KGF-1 as well as other actions that impact their effectiveness; these GF are described separately [21, 79].

As summarized in Table 1, five additional RCT and ten nonRCT studies were added to the previous review. For each given clinical situation, we concluded the following guidelines:

\section{KGF intravenous (IV): Hematologic cancer - CT — prevention \\ Guideline: No guideline possible}

The evidence available for the use of hKGF-1 intravenously in hematologic patients treated with CT is limited (LoE III). One RCT showed effectiveness in reducing severity of OM [7]. It was supported by another before-and-after study [77]. This study enrolled patients with $\mathrm{OM}$ in the first cycle of $\mathrm{CT}$, and showed less severe and shorter OM following intravenous hKGF-1 in second cycle of CT [77]. Due to the limited evidence, no guideline is possible.

\section{KGF (IV): Hematologic cancer - HSCT - prevention Guideline: Recommendation (LoE I)}

The use of KGF-1 intravenously is recommended for prevention of OM in patients with hematological cancer undergoing autologous HSCT with a conditioning regimen that includes high dose chemotherapy and TBI.

The current systematic review supports the previous guideline in this clinical setting. KGF-1 is recommended for the prevention of $\mathrm{OM}$ in patients with hematological malignancies receiving high dose $\mathrm{CT}$ and TBI followed by autologous HSCT. Our recommendation is based on five RCTs; four of them had no major flaws in the study design $[4,50,51,82$, 84]. Two of these RCTs described the same patient population and are considered as a single study for the purpose of this analysis [82, 84]. Two new RCTs showing KGF-1 was effective in preventing $\mathrm{OM}$ were conducted in pediatric patients $[50,51]$. Another RCT reported that KGF-1 was not effective in preventing $\mathrm{OM}$ in patients undergoing autologous HSCT without TBI conditioning [5]; therefore, the guideline is limited only to HSCT conditioned with TBI.

\section{KGF (IV): Head and neck (H\&N) cancers - RT-CT - prevention Guideline: No guideline possible}

There were three RCTs in this category [8, 29, 48]. Although all available studies showed some effectiveness of KGF-1 for prevention of OM in H\&N cancer patients undergoing RT-CT $[8,29,48]$, analyses of reported results were inconclusive of the effectiveness. Two RCTs showed statistically significant reduction of severe OM incidence but the authors concluded that the clinical relevance of this finding is unclear considering lack of difference between the study and placebo group in regards to patient reported outcomes or treatment breaks [29, 48]. A previous study suggested that in a post hoc analysis KGF-1 was only marginally effective to reduce $\mathrm{OM}$ in hyperfractionated RT in H\&N cancer patients [8].

\section{KGF (IV): Solid cancers - CT — prevention Guideline: No guideline possible}

Two reports for the use of KGF-1 as preventive measure of OM in cancer patients receiving CT showed effectiveness (Table 1) $[68,90]$. These studies were conducted in two different patient populations (colorectal cancer vs sarcoma) treated in different chemotherapy protocols (5-fluorouracil vs doxorubicin and ifosfamide). Another RCT in colorectal cancer patients treated with 5-fluorouracil compared 6 doses of KGF-1 to placebo and reached marginal significance $(p=0.06)$ [57]. No additional studies were found since the last guidelines update; therefore, there is no change to the guideline.

\section{CSF}

CSF are specific hematopoietic growth factors required for bone marrow progenitor cells to form mature blood cells. Data from basic science research suggest the mechanism of action of GCSF in wound healing: Granulocyte colony-stimulating factor (G-CSF) stimulates development of neutrophils, eosinophils, and basophils, whereas granulocyte-macrophage colonystimulating factor (GM-CSF) stimulates generation of cells belonging to the monocyte/macrophage lineage [37]. G-CSF and GM-CSF enhance the function of tissue neutrophils such as those present in the mucosa. Animal studies showed that GMCSF promotes proliferation of keratinocytes and enhances wound healing including mucosal barrier injuries $[3,37]$.

For G-CSF, one additional RCT and two cohort studies were added to the previous review (Table 2). Based on the new evidence, a clinical category for G-CSF was added compared to the 2013 Guideline Update.

There was only one additional RCT regarding GM-CSF, and it was added to the previous guidelines (Table 3). The guideline for the use of GM-CSF (systemic or topical) remains the same as previous guideline.

\section{G-CSF subcutaneous (SC): H\&N cancers - CT - prevention Guideline: No guideline possible}

The RCTs regarding the effectiveness of G-CSF for the prevention of $\mathrm{OM}$ in $\mathrm{H} \& \mathrm{~N}$ cancer patients are conflicting. A 


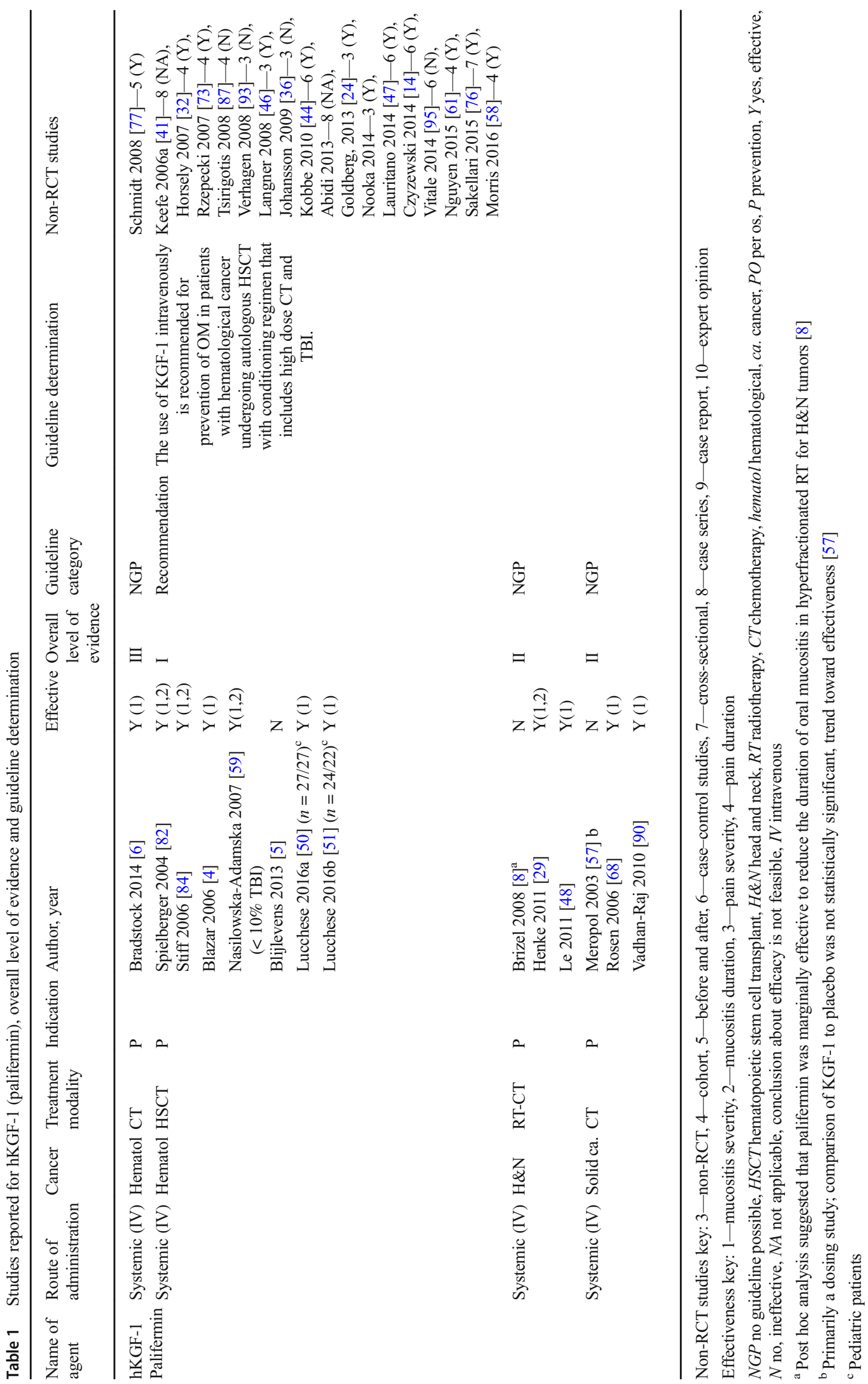


small RCT reported preliminary results suggesting G-CSF was not effective [78]. Another small RCT reported nonsignificant trend for a beneficial effect of G-CSF, and significant result for survival, but the study was closed prematurely due to low accrual [86]. The guideline remains no guideline possible.

\section{G-CSF SC: Solid cancers - CT — prevention Guideline: No guideline possible}

A single new cohort study about G-CSF was published since the previous Guidelines Update [65]. This did not report data about OM rather about its tolerability. Overall, the evidence for this agent was insufficient to reach a guideline.

G-CSF (topical or systemic): Hematological cancers - CT prevention

Guideline: No guideline possible

The panel concluded that no guideline could be provided for the use of G-CSF for prevention of OM in hematological cancer patients due to limited information about the effectiveness for either topical or systemic application [39, 64]. A RCT and a cohort study about this agent have been published since the last update investigating the use of G-CSF under the same clinical situation; these were excluded because they were not directly investigating OM $[16,85]$.

\section{G-CSF (topical): Solid cancers - CT — treatment Guideline: No guideline possible}

One cohort study involved the use of topical G-CSF to treat OM in 14 patients [97]. Due to the limited evidence, no guideline was possible in this category.

\section{GM-CSF (SC): H\&N cancers - RT or RT-CT — prevention Guideline: No guideline possible}

The additional RCT reviewed in this update showed no effectiveness for systemic GM-CSF in prevention of OM for patients undergoing RT to the H\&N. Therefore, the guideline remains the same. All studies in this clinical setting enrolled $\mathrm{H} \& \mathrm{~N}$ patients treated with RT only $[30,55,56]$. The only exception was a single RCT which included a mix of $\mathrm{H} \& \mathrm{~N}$ cancer patients treated with RT or RT-CT [72].

There was a comparator study in this clinical setting comparing GM-CSF to sucralfate [52]. The study concluded that there was no difference between the study groups in regard to OM grade, pain, and the use of analgesics. 


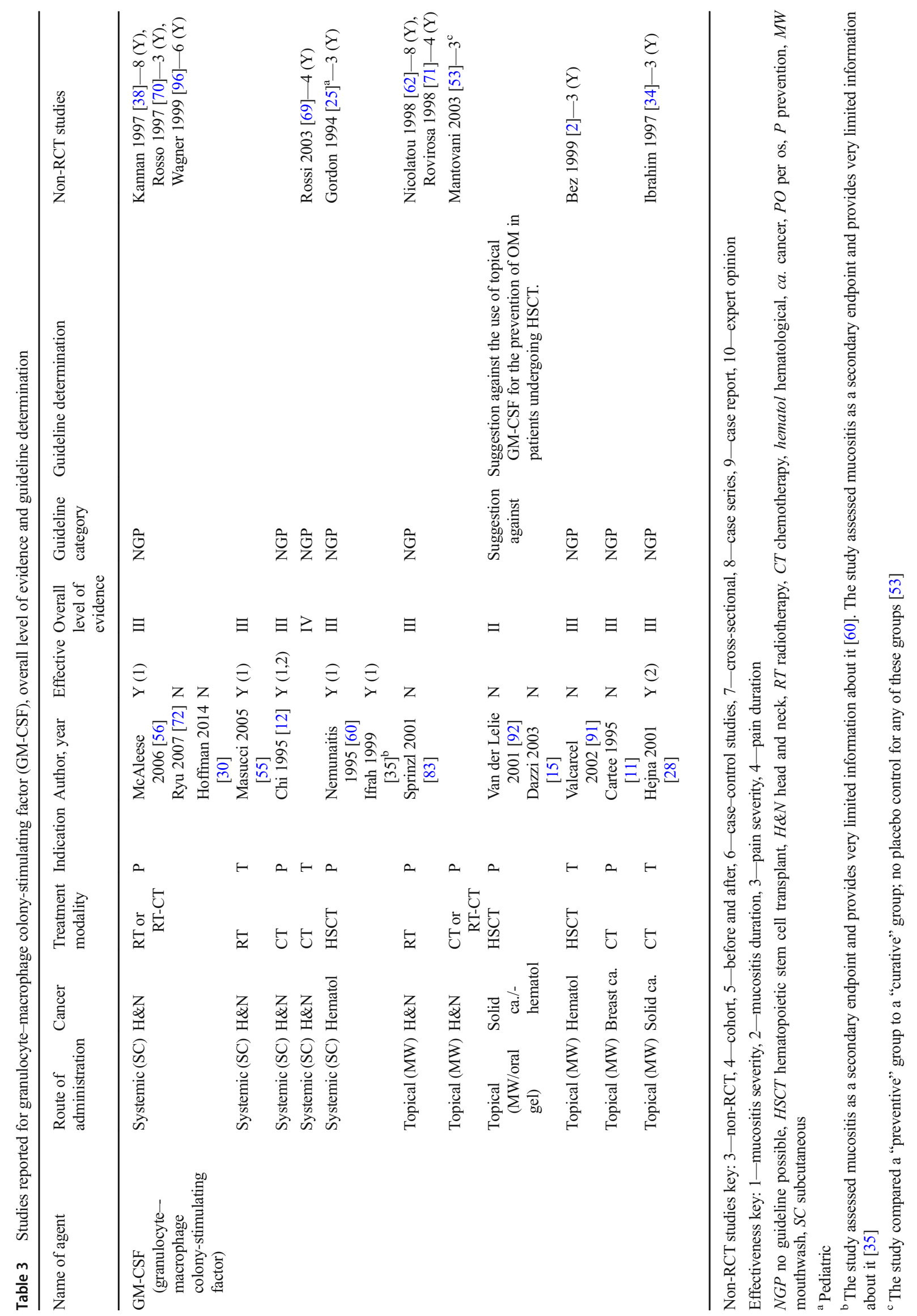




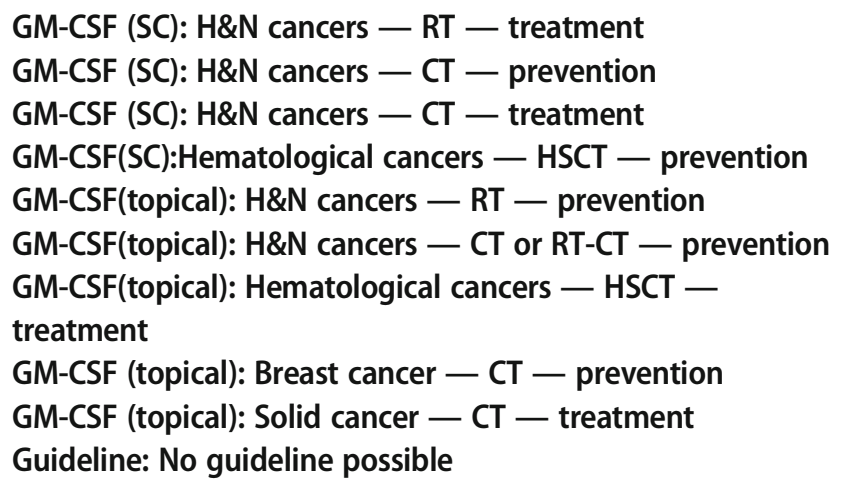

For these categories, there was limited evidence and no new data since the previous guidelines update (Table 3), therefore no guideline possible.

A RCT comparing GM-CSF mouthwash to sucralfate for the prevention of OM in $\mathrm{H} \& \mathrm{~N}$ cancer patients treated with RT was reported [74]. The study concluded that GM-CSF mouthwash may be moderately more effective than sucralfate.

\section{GM-CSF (topical): Solid/hematological cancer — HSCT — prevention}

Guideline: Suggestion against topical use in HSCT (LoE II)

The evidence suggests that topical GM-CSF should not be used for the prevention of $\mathrm{OM}$ in patients undergoing HSCT.

Two RCTs $[15,92]$ showed no effectiveness of GM$\mathrm{CSF}$ in the prevention of $\mathrm{OM}$ in this clinical setting. Accordingly, a guideline against the use of GM-CSF mouthwash for prevention of OM in patients undergoing autologous or allogeneic HSCT was made. Of note, the evidence for this guideline included a flawless large RCT study showing no effectiveness in regard to improving frequency of OM, mean duration of OM, OM-associated pain, and opioid use [15]. These studies were conducted when the conditioning regimen included TBI [92] and without TBI [15]. No new studies were found in this category; therefore, the guideline is unchanged.

\section{EGF}

Epidermal growth factor (EGF) is a polypeptide that plays an important role maintaining tissue homeostasis by regulating epithelial cell proliferation, growth, and migration [63]. EGF enhances mucosal wound healing and tissue generation, which was the basis for clinical studies in the treatment of OM.

There was one additional RCT using recombinant human epidermal growth factor (rhEGF) that was added to the previous guideline (Table 4).
rhEGF (topical): Hematological cancers - HSCT prevention

Guideline: No guideline possible

A new RCT was identified in this clinical setting for this systematic review [43]. The RCT showed that rhEGF was effective in reducing duration of $\mathrm{OM}$ but not in reducing severity of OM. Considering the limited data, no guideline is possible.

\section{rhEGF (topical): H\&N cancers - RT-CT - prevention} Guideline: No guideline possible

A single RCT in this clinical category compared various doses of rhEGF to placebo for prevention of OM [98]. Approximately half of the patients received concurrent CT. The study concluded that rhEGF was effective. Considering the limited data in this category and the need of safety data on larger samples and longer follow up, no guideline is possible

\section{rhEGF (topical): Solid cancer - CT — prevention Guideline: No guideline possible}

\section{EPO}

Erythropoietin (EPO) is a hematopoietic factor, produced mainly in the kidney via an oxygen-sensing mechanism. It stimulates the proliferation of erythroid progenitors in the bone marrow, leading to red blood cell production [10]. Recombinant human EPO is used to treat anemia. EPO also has anti-inflammatory effects by inhibiting NF-kB-dependent formation of a number of pro-inflammatory cytokines and carries antioxidant properties [9]. In one animal woundhealing model, the topical use of EPO-containing creams in wounds of diabetic rats showed a decrease in amount of apoptosis in a dose-dependent manner [27]. There are limited clinical studies of EPO efficacy in OM.

EPO (topical): Hematological cancers - HSCT - prevention Guideline: No guideline possible

There was a single well-designed RCT reviewed in this systematic review about EPO for prevention of OM in patients undergoing autologous HSCT [33]. It demonstrated effectiveness of EPO mouthwash as a preventive measure reducing incidence and duration of OM (Table 4). This RCT is the first of its kind using EPO for OM. Due to the limited evidence, no guideline is possible.

Other interventions for which the evidence and guideline remains unchanged 
Table 4 Studies reported for recombinant human epidermal growth factor (rhEGF) and erythropoietin, overall level of evidence and guideline determination

\begin{tabular}{|c|c|c|c|c|c|c|c|c|c|}
\hline Name of agent & $\begin{array}{l}\text { Route of } \\
\text { administration }\end{array}$ & Cancer & $\begin{array}{l}\text { Treatment } \\
\text { modality }\end{array}$ & Indication & Author, year & Effective & $\begin{array}{l}\text { Overall level } \\
\text { of evidence }\end{array}$ & $\begin{array}{l}\text { Guideline } \\
\text { category }\end{array}$ & $\begin{array}{l}\text { Non-RCT } \\
\text { studies }\end{array}$ \\
\hline \multirow[t]{3}{*}{$\begin{array}{l}\text { rhEGF (recombinant human } \\
\text { epidermal growth factor) }\end{array}$} & $\begin{array}{l}\text { Topical (oral } \\
\text { spray) }\end{array}$ & Hematol & HSCT & $\mathrm{P}$ & $\underset{[43]}{\operatorname{Kim} 2013}$ & Y (2) & III & NGP & \\
\hline & Topical $^{\mathrm{a}}$ & $\mathrm{H} \& \mathrm{~N}$ & RT-CT & $\mathrm{P}$ & $\begin{array}{l}\text { Wu } 2009 \\
\quad[98]\end{array}$ & Y (1) & III & NGP & $\begin{array}{l}\text { Hong } 2009 \\
{[31]-(4)} \\
\text { Y }\end{array}$ \\
\hline & Topical (MW) & $\begin{array}{l}\text { Small cell } \\
\text { lung } \\
\text { cancer }\end{array}$ & $\mathrm{CT}$ & $\mathrm{P}$ & & $\mathrm{N}$ & III & NGP & $\begin{array}{l}\text { Girdler } 1995 \\
{[23]-(3)} \\
\mathrm{N}\end{array}$ \\
\hline Erythropoietin & Topical (MW) & Hematol & HSCT & $\mathrm{P}$ & $\begin{array}{l}\text { Hosseinjani } \\
2015 \text { [33] }\end{array}$ & $\mathrm{Y}(1,2)$ & II & NGP & \\
\hline
\end{tabular}

Non-RCT studies key: 3 - non-RCT, 4 - cohort, 5-before and after, 6 - case-control studies, 7—cross-sectional, 8-case series, 9-case report, 10 expert opinion

Effectiveness key: 1-mucositis severity, 2-mucositis duration, 3-pain severity, 4 - pain duration

$N G P$ no guideline possible, $H S C T$ hematopoietic stem cell transplant, $H \& N$ head and neck, $R T$ radiotherapy, $C T$ chemotherapy, hematol hematological, $c a$. cancer, $P O$ per os, $P$ prevention, $M W$ mouthwash

${ }^{a}$ Oral spray then swallow

The current update did not yield any new studies for agents listed in Table 5. The guidelines remain the same as previously determined; no guideline is possible.

\section{Discussion}

This systematic review provides updated clinical guidelines for the use of cytokines and GF agents in the management of OM. New evidence was reported since the previous guidelines update [66] about KGF-1, G-CSF, GM-CSF, EGF, and EPO.

In support of previously determined guidelines, the current evidentiary update continues recommending the use of KGF-1 (IV) for the prevention of $\mathrm{OM}$ in patients with hematological cancer undergoing autologous HSCT when the conditioning regimen includes TBI. The LoE for this recommendation was upgraded from LoE II to LoE I.

Interestingly, this guideline is based on evidence in adult patients; however, there is new promising evidence indicating that this guideline may also be applicable for pediatric patients $[50,51]$. This guideline is limited to HSCT where its conditioning includes TBI because the evidence about efficacy was available exclusively when TBI was delivered $[4,50,51,82]$. This was reported also in a large retrospective comparative study demonstrating that palifermin decreased total parenteral nutrition, patient controlled analgesia, and length of stay at the hospital following TBI-based but not chemotherapy onlybased -HSCT [24] allogeneic.

Table 5 Interventions for which the evidence and guideline are unchanged, based on existing literature (adapted from Raber-Durlacher [66])

\begin{tabular}{|c|c|c|c|c|c|}
\hline Aim & Agent & Route of administration & Patient population & $\begin{array}{l}\text { Treatment } \\
\text { modality }\end{array}$ & Guideline \\
\hline $\mathrm{P}$ & Velafermin (FGF-20) & Systemic (IV) & Hematol & Auto HSCT & NGP \\
\hline $\mathrm{P}$ & Repifermin (KGF-2) & Systemic (IV) & Hematol & Auto HSCT & NGP \\
\hline $\mathrm{P}$ & Milk-derived protein extract & Topical (MW) & Hematol & Auto HSCT & NGP \\
\hline $\mathrm{T}$ & $\begin{array}{l}\text { Recombinant human intestinal trefoil factor } \\
\text { (rhITF) }\end{array}$ & Topical (oral spray) & Colorectal ca. & $\mathrm{CT}$ & NGP \\
\hline $\mathrm{P}$ & Recombinant human interleukin-11 (IL-11) & Systemic (SC) & Hematol & Allo HSCT & NGP \\
\hline $\mathrm{P}$ & ATL-104 & Topical (MW) & Hematol & Auto HSCT & NGP \\
\hline $\mathrm{P}$ & Transforming growth factor-B (TGF-B) & Topical (MW) & $\begin{array}{l}\text { Solid } \\
\text { cancer/hematol }\end{array}$ & $\mathrm{CT}$ & NGP \\
\hline $\mathrm{P}$ & Transforming growth factor-B (TGF-B) & $\begin{array}{l}\text { Topical (MW or TGF- } \beta 2 \text {-enriched } \\
\text { feeding) }\end{array}$ & $\begin{array}{l}\text { Hematol/bone } \\
\text { tumor }^{\mathrm{a}}\end{array}$ & $\mathrm{CT}$ & NGP \\
\hline
\end{tabular}

\footnotetext{
${ }^{\mathrm{a}}$ Pediatric patients
}

$N G P$ no guideline possible, $H S C T$ hematopoietic stem cell transplant, $H \& N$ head and neck, $R T$ radiotherapy, $C T$ chemotherapy, hematol hematological, ca. cancer, $P O$ per os, $P$ prevention, $I V$ intravenous, $M W$ mouthwash, $S C$ subcutaneous Auto autologous, Allo allogeneic 
While the 2013 guideline was limited to autologous HSCT, there is increasing evidence that this may be applicable for allogeneic HSCT $[4,51,59]$. However, the evidence in allogeneic HSCT was in variable patient populations in regard to the patient's age and inclusion of TBI in the conditioning regimen. Therefore, the scope of the current guideline remained for autologous HSCT only.

It should be highlighted however that there is regional variation in the ability to use KGF-1 (Palifermin, Kepivance). Since the previous MASCC/ISOO guideline update was published, the approval for the use of this drug was withdrawn within the European Union by the European Medicines Agency (EMA) [17]. Per the information on the EMA website, the withdrawal was at the request of the marketing authorization holder, which notified the European Commission of its decision to permanently discontinue the marketing of the product for commercial reasons [18]. Conversely, the drug is still approved for use in the USA by the FDA [88]. This was reconfirmed on the US National Cancer Institute (NCI) webpage on March 2018 [89].

In the 2013 guideline update, a suggestion against the use of topical GM-CSF for the prevention of OM in patients undergoing HSCT was made. No new evidence has been reported for this agent in the clinical setting since 2013 . Therefore, this guideline remains valid.

New evidence was published that introduced certain agents in a new clinical setting. These included G-CSF in patients with solid cancers treated with $\mathrm{CT}$ and rhEGF and EPO in patients undergoing HSCT. However, the evidence in these new categories did not reach the threshold for a guideline.

It was reported that when the intervals between doses of palifermin were shorter, as happened in the high-dose melphalan conditioning regimen, without TBI, prior to autologous HSCT, there were more adverse effects including skin problems, orofacial swelling, mucosal ulceration, and taste alterations [93]. Importantly, palifermin did not affect graft-versushost disease (GVHD), graft failure, or relapse [24]. These findings were supported by a study from the Center for International Blood and Marrow Transplant Research (CIBMTR) database which reported that in univariate analyses, two-year survival and disease-free survival rates after allogeneic HSCT and after autologous HSCT were similar between palifermin-treated patients and matched controls [75]. Additionally, in multivariate analysis, palifermin did not significantly increase the risk of mortality or relapse compared with matched controls. No significant differences in rates of

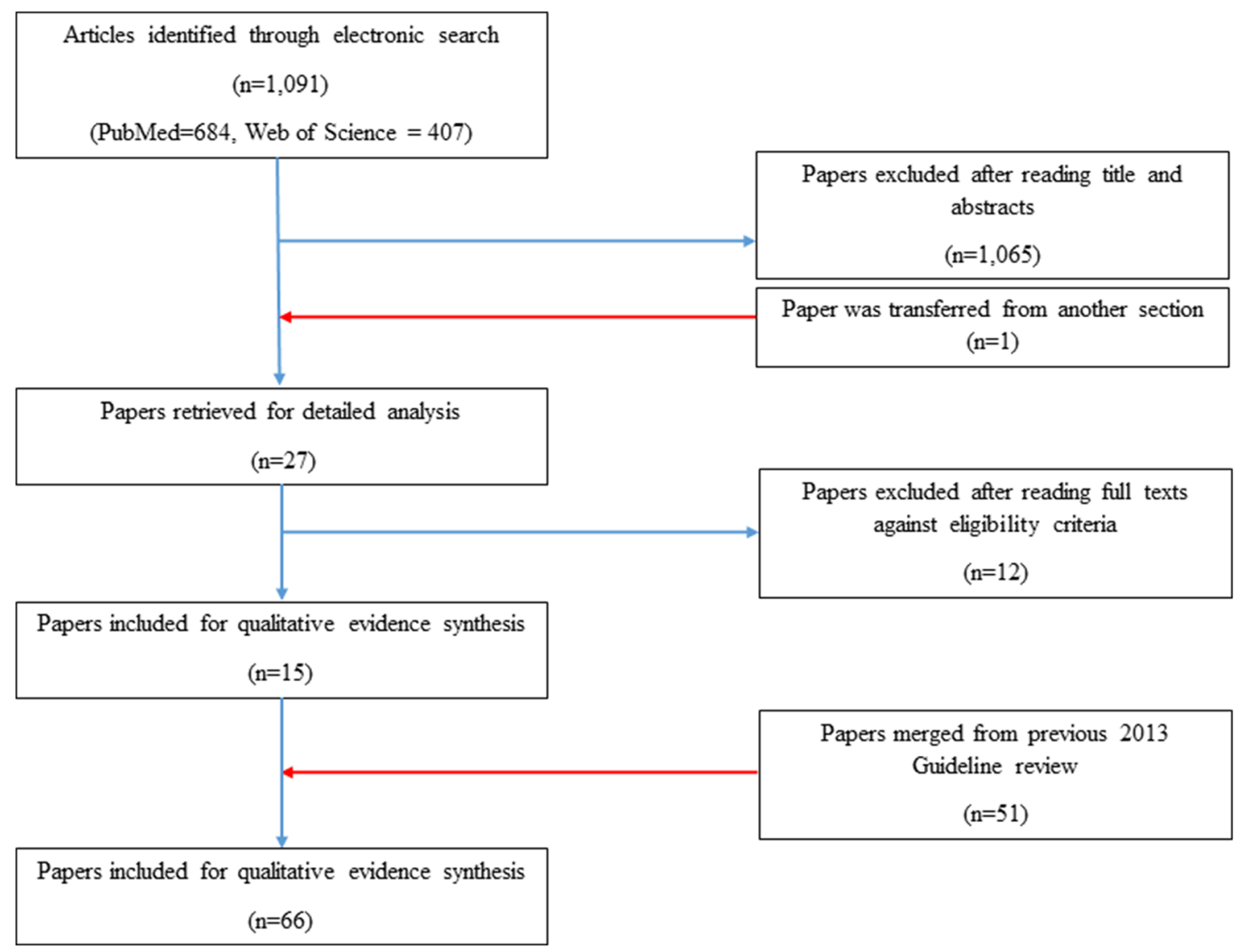

Fig. 1 Article flow chart throughtout the systematic review 
acute or chronic GVHD were observed between palifermintreated patients and matched controls [75]. Nevertheless, these long-term safety data were obtained at 31 months following administration of palifermin. To our best knowledge, there are no data regarding the 5-year relapse and overall survival postadministration of palifermin for prevention of $\mathrm{OM}$.

A Cochrane review about GF and cytokines for the prevention of OM concluded that in regard to adult patients undergoing HSCT, the group was less confident about a benefit for KGF-1 because of multiple factors involved in that population, such as whether or not they received TBI, and whether the transplant was autologous or allogeneic. Likewise, the Cochrane group concluded that KGF-1 was beneficial in the prevention of OM in adults who are receiving: (a) RT to the $\mathrm{H} \& \mathrm{~N}$ with cisplatin or fluorouracil or (b) $\mathrm{CT}$ alone for mixed solid and hematological cancers. Noticeably, there was difference between the MASCC/ISOO methodology and the Cochrane group methodology in regards to inclusion of RCTs that calculated the efficacy based on area under the curve, in the clinical interpretation of the evidence in $H \& N$ cancer patients $[8,29,48]$, and in the separation of evidence based on the cancer type $[6,57,68,90]$.

KGF-1 (palifermin) is administered systemically in all the RCTs that reported its use. Therefore, the question of safety is of greater importance relative to topical agents. Of relevance to the studies about prevention of OM with KGF-1 in patients with $H \& N$ cancer, KGF can induce proliferation of epithelial cell lines. Until long-term safety data about KGF in patients with $\mathrm{H} \& \mathrm{~N}$ cancer are available, the interpretation of the data about the clinical efficacy needs to be considered carefully.

The fact that various growth factors (KGF, G-CSF, GMCSF, EGF, and EPO), each effecting a different cell line (keratinocytes, granulocytes, macrophages, fibroblasts, erythrocytes, respectively), were suggested as interventions for OM reflects the complexity of the healing process of OM and the delicate balance needed between all these components to maintain the oral mucosal integrity.

Since the cutoff date for the literature review, a RCT was published testing the efficacy of topical rhEGF as an oral spray for the prevention OM in patients undergoing HSCT [42]. This report was an extension of a previous publication [43] concluding that rhEGF was effective for the prevention of OM. However, the later and larger report concluded that rhEGF was ineffective for the prevention of OM. Another RCT, designed as a comparator study, used rhEGF as a control while testing a Chinese medicine for the prevention of RT-associated OM [97]. A RCT comparing IV KGF versus chlorhexidine in pediatric patients with hematological cancers treated with $\mathrm{CT}$ reported that KGF reduced the severity of OM [22].

In summary, for the interventions reviewed in this paper, the available evidence supported a recommendation for KGF1 (palifermin) for the prevention of $\mathrm{OM}$ in a well-defined clinical setting. Likewise, based on the previously reported evidence, the suggestion against topical GM-CSF for the prevention of mucositis is validated. Considering the growing body of evidence, the guidelines about the agents covered in this section will require updating in the future (Fig. 1).

Acknowledgments The authors are thankful for the medical librarians for their valuable contribution to this project: Lorraine Porcello, MSLIS, MSIM-Bibby Dental Library, Eastman Institute for Oral Health, University of Rochester Medical Center, Rochester, NY, USA; Daniel A. Castillo, MLIS - Edward G. Miner Library, University of Rochester Medical Center, Rochester, NY, USA.

\section{Compliance with ethical standards}

Conflict of interest Per MASCC Guidelines Policy, employees of commercial entities were not eligible to serve on this MASCC Guidelines Panel. PB has served an advisory role for AstraZeneca, Helsinn, and Kyowa Kyrin and received grants from Merck, Kyowa Kyrin, and Roche. RVL has served as a consultant for Alira Health, Colgate Oral Pharmaceuticals, Galera Therapeutics, Ingalfarma SA, Monopar Therapeutics, Mundipharma, and Sucampo Pharma; has received research support to his institution from Galera Therapeutics, Novartis, Oragenics, and Sucampo Pharma; and has received stock in Logic Biosciences. SE Discloses no conflict of interest in regards to the subject matter, and serve as a consultant for Falk Pharma outside the submitted work.

\section{References}

1. Abitbol AA, Sridhar KS, Lewin AA, Schwade JG, Raub W Jr, Wolfson A, Gonzalez-Angulo C, Adessa A, Goodwin WJ, Markoe AM (1997) Hyperfractionated radiation therapy and 5fluorouracil, cisplatin, and mitomycin-C (+/- granulocyte-colony stimulating factor) in the treatment of patients with locally advanced head and neck carcinoma. Cancer 80:266-276

2. Bez C, Demarosi F, Sardella A, Lodi G, Bertolli VG, Annaloro C, Rimondini L, Porter SR, Carrassi A (1999) GM-CSF mouthrinses in the treatment of severe oral mucositis: a pilot study. Oral Surg Oral Med Oral Pathol Oral Radiol Endod 88:311-315

3. Bianchi L, Ginebri A, Hagman JH, Francesconi F, Carboni I, Chimenti S (2002) Local treatment of chronic cutaneous leg ulcers with recombinant human granulocyte-macrophage colony-stimulating factor. J Eur Acad Dermatol Venereol 16:595-598

4. Blazar BR, Weisdorf DJ, DeFor T, Goldman A, Braun T, Silver S, Ferrara JL (2006) Phase 1/2 randomized, placebo-control trial of palifermin to prevent graft-versus-host disease (GVHD) after allogeneic hematopoietic stem cell transplantation (HSCT). Blood 108: 3216-3222

5. Blijlevens N, de Chateau M, Krivan G, Rabitsch W, Szomor A, Pytlik R, Lissmats A, Johnsen HE, de Witte T, Einsele H, Ruutu T, Niederwieser D (2013) In a high-dose melphalan setting, palifermin compared with placebo had no effect on oral mucositis or related patient's burden. Bone marrow transplantation 48:966971

6. Bradstock KF, Link E, Collins M, Di Iulio J, Lewis ID, Schwarer A, Enno A, Marlton P, Hahn U, Szer J (2014) A randomized trial of prophylactic palifermin on gastrointestinal toxicity after intensive induction therapy for acute myeloid leukaemia. Br J Haematol 167: 618-625

7. Bradstock KF, Link E, Collins M, Di Iulio J, Lewis ID, Schwarer A, Enno A, Marlton P, Hahn U, Szer JJBjoh (2014) A randomized trial of prophylactic palifermin on gastrointestinal toxicity after 
intensive induction therapy for acute myeloid leukaemia. Br J Haematol 167:618-625

8. Brizel DM, Murphy BA, Rosenthal DI, Pandya KJ, Glück S, Brizel HE, Meredith RF, Berger D, Chen M-G, Mendenhall W (2008) Phase II study of palifermin and concurrent chemoradiation in head and neck squamous cell carcinoma. J Clin Oncol 26:2489-2496

9. Broxmeyer HE (2013) Erythropoietin: multiple targets, actions, and modifying influences for biological and clinical consideration. $\mathrm{J}$ Exp Med 210:205-208

10. Cantarelli C, Angeletti A, Cravedi P (2019) Erythropoietin, a multifaceted protein with innate and adaptive immune modulatory activity American journal of transplantation : official journal of the American Society of Transplantation and the American Society of Transplant Surgeons

11. Cartee L, Petros WP, Rosner GL, Gilbert C, Moore S, Affronti ML, Hoke JA, Hussein AM, Ross M, Rubin P et al (1995) Evaluation of GM-CSF mouthwash for prevention of chemotherapy-induced mucositis: a randomized, double-blind, dose-ranging study. Cytokine 7:471-477

12. Chi KH, Chen CH, Chan WK, Chow KC, Chen SY, Yen SH, Chao JY, Chang CY, Chen KY (1995) Effect of granulocyte-macrophage colony-stimulating factor on oral mucositis in head and neck cancer patients after cisplatin, fluorouracil, and leucovorin chemotherapy. Journal of clinical oncology : official journal of the American Society of Clinical Oncology 13:2620-2628

13. Crawford J, Tomita DK, Mazanet R, Glaspy J, Ozer H (1999) Reduction of oral mucositis by filgrastim (r-metHuG-CSF) in patients receiving chemotherapy. Cytokines Cell Mol Ther 5:187-193

14. Czyzewski K, Debski R, Krenska A, Wysocki M, Styczynski J (2014) Palifermin in children undergoing autologous stem cell transplantation: a matched-pair analysis. Anticancer Res 34:73797382

15. Dazzi C, Cariello A, Giovanis P, Monti M, Vertogen B, Leoni M, Tienghi A, Turci D, Rosti G, Nanni O, Rondoni C, Marangolo M (2003) Prophylaxis with GM-CSF mouthwashes does not reduce frequency and duration of severe oral mucositis in patients with solid tumors undergoing high-dose chemotherapy with autologous peripheral blood stem cell transplantation rescue: a double blind, randomized, placebo-controlled study. Ann Oncol 14:559-563

16. Ellis GK, Barlow WE, Gralow JR, Hortobagyi GN, Russell CA, Royce ME, Perez EA, Lew D, Livingston RB (2011) Phase III comparison of standard doxorubicin and cyclophosphamide versus weekly doxorubicin and daily oral cyclophosphamide plus granulocyte colony-stimulating factor as neoadjuvant therapy for inflammatory and locally advanced breast cancer: SWOG 0012. Journal of clinical oncology : official journal of the American Society of Clinical Oncology 29:1014-1021

17. Kepivance. Accessed 28 July 2019, from https://www.ema.europa. $\mathrm{eu} / \mathrm{en} / \mathrm{medicines} / \mathrm{human} / \mathrm{EPAR} /$ kepivance.

18. Kepivance: withdrawal of the marketing authorisation in the European Union. Accessed 28 July 2019, from https://www.ema. europa.eu/en/documents/public-statement/public-statementkepivance-withdrawal-marketing-authorisation-european-union en.pdf].

19. Epstein JB, Thariat J, Bensadoun RJ, Barasch A, Murphy BA, Kolnick L, Popplewell L, Maghami E (2012) Oral complications of cancer and cancer therapy: from cancer treatment to survivorship. CA: a cancer journal for clinicians 62:400-422

20. Farrell C, Rex K, Chen J, Bready J, DiPalma C, Kaufman S, Rattan A, Scully S, Lacey D (2002) The effects of keratinocyte growth factor in preclinical models of mucositis. Cell proliferation 35:7885

21. Freytes CO, Ratanatharathorn V, Taylor C, Abboud C, Chesser N, Restrepo A, Arango J, Odenheimer D (2004) Phase I/II randomized trial evaluating the safety and clinical effects of repifermin administered to reduce mucositis in patients undergoing autologous hematopoietic stem cell transplantation. Clin Cancer Res 10: 8318-8324

22. Gholizadeh N, Mehdipoor M, Sajadi H, Moosavi M-S (2016) Palifermin and chlorhexidine mouthwashes in prevention of chemotherapy-induced mucositis in children with acute lymphocytic leukemia: a randomized controlled trial. Journal of Dentistry 17: 343

23. Girdler NM, McGurk M, Aqual S, Prince M (1995) The effect of epidermal growth factor mouthwash on cytotoxic-induced oral ulceration. A phase I clinical trial Am J Clin Oncol 18:403-406

24. Goldberg JD, Zheng J, Castro-Malaspina H, Jakubowski AA, Heller G, van den Brink MR, Perales M-A (2013) Palifermin is efficacious in recipients of TBI-based but not chemotherapybased allogeneic hematopoietic stem cell transplants. Bone Marrow Transplant 48:99

25. Gordon B, Spadinger A, Hodges E, Ruby E, Stanley R, Coccia PJJoCO (1994) Effect of granulocyte-macrophage colony-stimulating factor on oral mucositis after hematopoietic stem-cell transplantation. J Clin Oncol 12:1917-1922

26. Hadorn DC, Baker D, Hodges JS, Hicks N (1996) Rating the quality of evidence for clinical practice guidelines. J Clin Epidemiol 49: 749-754

27. Hamed S, Bennett CL, Demiot C, Ullmann Y, Teot L, Desmouliere A (2014) Erythropoietin, a novel repurposed drug: an innovative treatment for wound healing in patients with diabetes mellitus. Wound repair and regeneration : official publication of the Wound Healing Society [and] the European Tissue Repair Society 22:2333

28. Hejna M, Kostler WJ, Raderer M, Steger GG, Brodowicz T, Scheithauer W, Wiltschke C, Zielinski CC (2001) Decrease of duration and symptoms in chemotherapy-induced oral mucositis by topical GM-CSF: results of a prospective randomised trial. Eur J Cancer 37:1994-2002

29. Henke M, Alfonsi M, Foa P, Giralt J, Bardet E, Cerezo L, Salzwimmer M, Lizambri R, Emmerson L, Chen M-G (2011) Palifermin decreases severe oral mucositis of patients undergoing postoperative radiochemotherapy for head and neck cancer: a randomized, placebo-controlled trial. Journal of clinical oncology : official journal of the American Society of Clinical Oncology 29: $-2815,2820$

30. Hoffman KE, Pugh SL, James JL, Scarantino C, Movsas B, Valicenti RK, Fortin A, Pollock J, Kim H, Brachman DG, Berk LB, Bruner DW, Kachnic LA (2014) The impact of concurrent granulocyte-macrophage colony-stimulating factor on quality of life in head and neck cancer patients: results of the randomized, placebo-controlled Radiation Therapy Oncology Group 9901 trial. Qual Life Res 23:1841-1858

31. Hong J, Lee SW, Song S, Ahn S, Shin S, Choi E, Kim J (2009) Recombinant human epidermal growth factor treatment of radiation-induced severe oral mucositis in patients with head and neck malignancies. European journal of cancer care 18:636-641

32. Horsley P, Bauer JD, Mazkowiack R, Gardner R, Bashford J (2007) Palifermin improves severe mucositis, swallowing problems, nutrition impact symptoms, and length of stay in patients undergoing hematopoietic stem cell transplantation. Support Care Cancer 15: 105-109

33. Hosseinjani H, Hadjibabaie M, Gholami K, Javadi M, Radfar M, Jahangard-Rafsanjani Z, Hosseinjani E, Shabani N, Vaezi M, Ghavamzadeh A (2017) The efficacy of erythropoietin mouthwash in prevention of oral mucositis in patients undergoing autologous hematopoietic SCT: a double-blind, randomized, placebocontrolled trial. Hematol Oncol 35:106-112

34. Ibrahim EM, al-Mulhim FA (1997) Effect of granulocytemacrophage colony-stimulating factor on chemotherapy-induced oral mucositis in non-neutropenic cancer patients. Med Oncol 14: $47-51$ 
35. Ifrah N, Witz F, Jouet JP, Francois S, Lamy T, Linassier C, Pignon B, Berthou C, Guyotat D, Cahn JY, Harousseau JL (1999) Intensive short term therapy with granulocyte-macrophage-colony stimulating factor support, similar to therapy for acute myeloblastic leukemia, does not improve overall results for adults with acute lymphoblastic leukemia. GOELAMS Group Cancer 86:1496-1505

36. Johansson JE, Hasseus B, Johansson P, Eklof C, Ohman D, Stockelberg D (2009) Gut protection by palifermin during autologous haematopoietic. SCT Bone Marrow Transplant 43:807-811

37. Jyung RW, Wu L, Pierce GF, Mustoe TA (1994) Granulocytemacrophage colony-stimulating factor and granulocyte colonystimulating factor: differential action on incisional wound healing. Surgery 115:325-334

38. Kannan V, Bapsy PP, Anantha N, Doval DC, Vaithianathan H, Banumathy G, Reddy KB, Kumaraswamy SV, Shenoy AM (1997) Efficacy and safety of granulocyte macrophage-colony stimulating factor (GM-CSF) on the frequency and severity of radiation mucositis in patients with head and neck carcinoma. Int J Radiat Oncol Biol Phys 37:1005-1010

39. Karthaus M, Rosenthal C, Huebner G, Paul H, Elser C, Hertenstein B, Krauter J, Scharmann T, Geissler RG, Heil G, Ganser A (1998) Effect of topical oral G-CSF on oral mucositis: a randomised placebo-controlled trial. Bone Marrow Transplant 22:781-785

40. Katano M, Nakamura M, Matsuo T, Iyama A, Hisatsugu T (1995) Effect of granulocyte colony-stimulating factor (G-CSF) on chemotherapy-induced oral mucositis. Surg Today 25:202-206

41. Keefe D, Lees J, Horvath N (2006) Palifermin for oral mucositis in the high-dose chemotherapy and stem cell transplant setting: the Royal Adelaide Hospital Cancer Centre experience. Support Care Cancer 14:580-582

42. Kim J-W, Kim MG, Lee HJ, Koh Y, Kwon J-H, Kim I, Park S, Kim BK, Oh JM, Im Kim K (2017) Topical recombinant human epidermal growth factor for oral mucositis induced by intensive chemotherapy with hematopoietic stem cell transplantation: final analysis of a randomized, double-blind, placebo-controlled, phase 2 trial. PloS one 12:e0168854

43. Kim KI, Kim JW, Lee HJ, Kim BS, Bang SM, Kim I, Oh JM, Yoon SS, Lee JS, Park S (2013) Recombinant human epidermal growth factor on oral mucositis induced by intensive chemotherapy with stem cell transplantation. Am J Hematol 88:107-112

44. Kobbe G, Bruns I, Schroeder T, Czibere A, Warnecke J, Hieronimus N, Safaian N, Kondakci M, Saure C, Germing U, Haas R, Fenk R (2010) A 3-day short course of palifermin before HDT reduces toxicity and need for supportive care after autologous blood stem-cell transplantation in patients with multiple myeloma. Ann Oncol 21:1898-1904

45. Lalla RV, Bowen J, Barasch A, Elting L, Epstein J, Keefe DM, McGuire DB, Migliorati C, Nicolatou-Galitis O, Peterson DE, Raber-Durlacher JE, Sonis ST, Elad S (2014) MASCC/ISOO clinical practice guidelines for the management of mucositis secondary to cancer therapy. Cancer 120:1453-1461

46. Langner S, Staber P, Schub N, Gramatzki M, Grothe W, Behre G, Rabitsch W, Urban C, Linkesch W, Neumeister P (2008) Palifermin reduces incidence and severity of oral mucositis in allogeneic stemcell transplant recipients. Bone Marrow Transplant 42:275-279

47. Lauritano D, Petruzzi M, Di Stasio D, Lucchese A (2014) Clinical effectiveness of palifermin in prevention and treatment of oral mucositis in children with acute lymphoblastic leukaemia: a casecontrol study. Int J Oral Sci 6:27-30

48. Le Q-T, Kim HE, Schneider CJ, Muraközy G, Skladowski K, Reinisch S, Chen Y, Hickey M, Mo M, Chen M-G (2011) Palifermin reduces severe mucositis in definitive chemoradiotherapy of locally advanced head and neck cancer: a randomized, placebo-controlled study. Journal of clinical oncology : official journal of the American Society of Clinical Oncology 29:28082814
49. Logan RM, Stringer AM, Bowen JM, Yeoh AS-J, Gibson RJ, Sonis ST, Keefe DM (2007) The role of pro-inflammatory cytokines in cancer treatment-induced alimentary tract mucositis: pathobiology, animal models and cytotoxic drugs. Cancer Treatment Rev 33:448460

50. Lucchese A, Matarese G, Ghislanzoni LH, Gastaldi G, Manuelli M, Gherlone EJL, lymphoma (2016) Efficacy and effects of palifermin for the treatment of oral mucositis in patients affected by acute lymphoblastic leukemia. 57:820-827

51. Lucchese A, Matarese G, Manuelli M, Ciuffreda C, Bassani L, Isola G, CordaSco G, Gherlone EJM (2016) Reliability and efficacy of palifermin in prevention and management of oral mucositis in patients with acute lymphoblastic leukemia: a randomized, doubleblind controlled clinical trial. Surgery $65: 43-50$

52. Makkonen TA, Minn H, Jekunen A, Vilja P, Tuominen J, Joensuu H (2000) Granulocyte macrophage-colony stimulating factor (GM$\mathrm{CSF}$ ) and sucralfate in prevention of radiation-induced mucositis: a prospective randomized study. Int J Radiat Oncol Biol Phys 46: 525-534

53. Mantovani G, Massa E, Astara G, Murgia V, Gramignano G, Lusso MR, Camboni P, Ferreli L, Mocci M, Perboni S, Mura L, Madeddu C, Maccio A (2003) Phase II clinical trial of local use of GM-CSF for prevention and treatment of chemotherapy- and concomitant chemoradiotherapy-induced severe oral mucositis in advanced head and neck cancer patients: an evaluation of effectiveness, safety and costs. Oncol Rep 10:197-206

54. Mascarin M, Franchin G, Minatel E, Gobitti C, Talamini R, De Maria D, Trovo MG (1999) The effect of granulocyte colonystimulating factor on oral mucositis in head and neck cancer patients treated with hyperfractionated radiotherapy. Oral Oncol 35: 203-208

55. Masucci G, Broman P, Kelly C, Lindahl S, Malmberg L, Reizenstein J, Alenius M, Lewensohn R (2005) Therapeutic efficacy by recombinant human granulocyte/monocyte-colony stimulating factor on mucositis occurring in patients with oral and oropharynx tumors treated with curative radiotherapy: a multicenter open randomized phase III study. Med Oncol 22:247-256

56. McAleese JJ, Bishop KM, A'Hern R, Henk JM (2006) Randomized phase II study of GM-CSF to reduce mucositis caused by accelerated radiotherapy of laryngeal cancer. Br J Radiol 79:608-613

57. Meropol NJ, Somer RA, Gutheil J, Pelley RJ, Modiano MR, Rowinsky EK, Rothenberg ML, Redding SW, Serdar CM, Yao B (2003) Randomized phase I trial of recombinant human keratinocyte growth factor plus chemotherapy: potential role as mucosal protectant. J Clin Oncol 21:1452-1458

58. Morris J, Rudebeck M, Neudorf S, Moore T, Duerst R, Shah AJ, Graham M, Aquino V, Morris C, Olsson B (2016) Safety, pharmacokinetics, and efficacy of palifermin in children and adolescents with acute leukemias undergoing myeloablative therapy and allogeneic hematopoietic stem cell transplantation: a pediatric blood and marrow transplant consortium trial. Biol Blood Marrow Transplant 22:1247-1256

59. Nasilowska-Adamska B, Rzepecki P, Manko J, Czyz A, Markiewicz M, Federowicz I, Tomaszewska A, PiatkowskaJakubas B, Wrzesien-Kus A, Bieniaszewska M (2007) The influence of palifermin (Kepivance) on oral mucositis and acute graft versus host disease in patients with hematological diseases undergoing hematopoietic stem cell transplant. Bone Marrow Transplant 40:983

60. Nemunaitis J, Rosenfeld CS, Ash R, Freedman MH, Deeg HJ, Appelbaum F, Singer JW, Flomenberg N, Dalton W, Elfenbein GJ et al (1995) Phase III randomized, double-blind placebo-controlled trial of rhGM-CSF following allogeneic bone marrow transplantation. Bone Marrow Transplant 15:949-954

61. Nguyen DT, Shayani S, Palmer J, Dagis A, Forman SJ, Epstein J, Spielberger R (2015) Palifermin for prevention of oral mucositis in 
allogeneic hematopoietic stem cell transplantation: a singleinstitution retrospective evaluation. Support Care Cancer 23: 3141-3147

62. Nicolatou O, Sotiropoulou-Lontou A, Skarlatos J, Kyprianou K, Kolitsi G, Dardoufas K (1998) A pilot study of the effect of granulocyte-macrophage colony-stimulating factor on oral mucositis in head and neck cancer patients during X-radiation therapy: a preliminary report. Int J Radiat Oncol Biol Phys 42:551-556

63. Noguchi S, Ohba Y, Oka T (1991) Effect of salivary epidermal growth factor on wound healing of tongue in mice. Am J Physiol 260:E620-E625

64. Patte C, Laplanche A, Bertozzi AI, Baruchel A, Frappaz D, Schmitt C, Mechinaud F, Nelken B, Boutard P, Michon J (2002) Granulocyte colony-stimulating factor in induction treatment of children with non-Hodgkin's lymphoma: a randomized study of the French Society of Pediatric Oncology. Journal of clinical oncology : official journal of the American Society of Clinical Oncology 20:441-448

65. Pietri E, Andreis D, Fabbri F, Menna C, Schirone A, Kopf B, Rocca A, Amadori D, De Giorgi U (2015) A phase II study of a dosedensity regimen with fluorouracil, epirubicin, and cyclophosphamide on days 1 and 4 every 14 days with filgrastim support followed by weekly paclitaxel in women with primary breast cancer. Oncologist 20:239-240

66. Raber-Durlacher JE, Von Bültzingslöwen I, Logan RM, Bowen J, Al-Azri AR, Everaus H, Gerber E, Gomez JG, Pettersson BG, Soga Y (2013) Systematic review of cytokines and growth factors for the management of oral mucositis in cancer patients. Supportive Care in Cancer 21:343-355

67. Ranna V, Cheng KKF, Castillo DA, Porcello L, Vaddi A, Lalla RV, Bossi P, Elad S (2019) Development of the MASCC/ISOO clinical practice guidelines for mucositis: an overview of the methods Support Care Cancer

68. Rosen LS, Abdi E, Davis ID, Gutheil J, Schnell FM, Zalcberg J, Cesano A, Gayko U, Chen M-G, Clarke S (2006) Palifermin reduces the incidence of oral mucositis in patients with metastatic colorectal cancer treated with fluorouracil-based chemotherapy. J Clin Oncol 24:5194-5200

69. Rossi A, Rosati G, Colarusso D, Manzione L (2003) Subcutaneous granulocyte-macrophage colony-stimulating factor in mucositis induced by an adjuvant 5 -fluorouracil plus leucovorin regimen. A phase II study and review of the literature Oncology 64:353-360

70. Rosso M, Blasi G, Gherlone E, Rosso R (1997) Effect of granulocyte-macrophage colony-stimulating factor on prevention of mucositis in head and neck cancer patients treated with chemoradiotherapy. J Chemother 9:382-385

71. Rovirosa A, Ferre J, Biete A (1998) Granulocyte macrophagecolony-stimulating factor mouthwashes heal oral ulcers during head and neck radiotherapy. Int J Radiat Oncol Biol Phys 41:747-754

72. Ryu JK, Swann S, LeVeque F, Scarantino CW, Johnson D, Chen A, Fortin A, Pollock J, Kim H, Ang KK (2007) The impact of concurrent granulocyte macrophage-colony stimulating factor on radiation-induced mucositis in head and neck cancer patients: a double-blind placebo-controlled prospective phase III study by Radiation Therapy Oncology Group 9901. Int J Radiat Oncol Biol Phys 67:643-650

73. Rzepecki P, Sarosiek T, Barzal J, Oborska S, Nurzynski P, Wasko A, Szczylik C (2007) Palifermin for prevention of oral mucositis after haematopoietic stem cell transplantation- single centre experience. J BUON 12:477-482

74. Saarilahti K, Kajanti M, Joensuu T, Kouri M, Joensuu H (2002) Comparison of granulocyte-macrophage colony-stimulating factor and sucralfate mouthwashes in the prevention of radiation-induced mucositis: a double-blind prospective randomized phase III study. Int J Radiat Oncol Biol Phys 54:479-485
75. Saber W, Zhang M-J, Steinert P, Chen M, Horowitz MM (2016) The impact of palifermin use on hematopoietic cell transplant outcomes in children. Biology of Blood and Marrow Transplantation 22:1460-1466

76. Sakellari I, Angelopoulou M, Tsopra O, Dervenoulas I, Tsirigotis P, Spyridonidis A, Liga M, Tsionos K, Anargyrou K, Pouli A Anagnostopoulos A (2015) A prospective study of incidence, clinical and quality of life consequences of oral mucositis post palifermin prophylaxis in patients undergoing high-dose chemotherapy and autologous hematopoietic cell transplantation. Ann Hematol 94:1733-1740

77. Schmidt E, Thoennissen N, Rudat A, Bieker R, Schliemann C, Mesters R, Zühlsdorf M, Müller-Tidow C, Berdel WJAoo (2008) Use of palifermin for the prevention of high-dose methotrexateinduced oral mucositis. 19:1644-1649

78. Schneider SB, Nishimura RD, Zimmerman RP, Tran L, Shiplacoff J, Tormey M, Contreras R, Juillard GF (1999) Filgrastim (rmetHuG-CSF) and its potential use in the reduction of radiationinduced oropharyngeal mucositis: an interim look at a randomized, double-blind, placebo-controlled trial Cytokines. Cell Mol Ther 5: $175-180$

79. Schuster MW, Shore TB, Harpel JG, Greenberg J, Jalilizeinali B, Possley S, Gerwien RW, Hahne W, Halvorsen Y-DC (2008) Safety and tolerability of velafermin (CG53135-05) in patients receiving high-dose chemotherapy and autologous peripheral blood stem cell transplant. Supportive Care in Cancer 16:477-483

80. Somerfield M, Padberg J, Pfister D, Bennett C, Recht A, Smith T, Weeks J, Winn R, Durant J (2000) ASCO clinical practice guidelines: process, progress, pitfalls, and prospects. Class Pap Curr Comments 4:881-886

81. Sonis ST, Elting LS, Keefe D, Peterson DE, Schubert M, HauerJensen M, Bekele BN, Raber-Durlacher J, Donnelly JP, Rubenstein EB (2004) Perspectives on cancer therapy-induced mucosal injury. Cancer 100:1995-2025

82. Spielberger R, Stiff P, Bensinger W, Gentile T, Weisdorf D, Kewalramani T, Shea T, Yanovich S, Hansen K, Noga S, McCarty J, LeMaistre CF, Sung EC, Blazar BR, Elhardt D, Chen MG, Emmanouilides C (2004) Palifermin for oral mucositis after intensive therapy for hematologic cancers. The New England journal of medicine 351:2590-2598

83. Sprinzl GM, Galvan O, de Vries A, Ulmer H, Gunkel AR, Lukas P, Thumfart WF (2001) Local application of granulocyte-macrophage colony stimulating factor (GM-CSF) for the treatment of oral mucositis. Eur J Cancer 37:2003-2009

84. Stiff PJ, Emmanouilides C, Bensinger WI, Gentile T, Blazar B, Shea TC, Lu J, Isitt J, Cesano A, Spielberger R (2006) Palifermin reduces patient-reported mouth and throat soreness and improves patient functioning in the hematopoietic stem-cell transplantation setting. Journal of clinical oncology : official journal of the American Society of Clinical Oncology 24:5186-5193

85. Straka C, Sandherr M, Salwender H, Wandt H, Metzner B, Hubel K, Silling G, Hentrich M, Franke D, Schwerdtfeger R, Freund M, Sezer O, Giagounidis A, Ehninger G, Grimminger W, Engert A, Schlimok G, Scheid C, Hellmann P, Heinisch H, Einsele H, Hinke A, Emmerich B (2011) Testing G-CSF responsiveness predicts the individual susceptibility to infection and consecutive treatment in recipients of high-dose chemotherapy. Blood 117:2121-2128

86. Su YB, Vickers AJ, Zelefsky MJ, Kraus DH, Shaha AR, Shah JP, Serio AM, Harrison LB, Bosl GJ, Pfister DG (2006) Double-blind, placebo-controlled, randomized trial of granulocyte-colony stimulating factor during postoperative radiotherapy for squamous head and neck cancer. Cancer J 12:182-188

87. Tsirigotis P, Triantafyllou K, Girkas K, Giannopoulou V, Ioannidou E, Chondropoulos S, Kalli T, Papaxoinis G, Pappa V, Papageorgiou E, Economopoulos T, Ladas SD, Dervenoulas J (2008) Keratinocyte growth factor is effective in the prevention of 
intestinal mucositis in patients with hematological malignancies treated with high-dose chemotherapy and autologous hematopoietic SCT: a video-capsule endoscopy study. Bone Marrow Transplant 42:337-343

88. Palifermin FDA approval. Accessed 28 July 2019, from https:// www.fda.gov/drugs/postmarket-drug-safety-information-patientsand-providers/palifermin-marketed-kepivance.

89. Palifermin FDA approval. Accessed 28 July 2019, from https:// www.cancer.gov/about-cancer/treatment/drugs/palifermin.

90. Vadhan-Raj S, Trent J, Patel S, Zhou X, Johnson MM, Araujo D, Ludwig JA, O'roark S, Gillenwater AM, Bueso-Ramos C (2010) Single-dose palifermin prevents severe oral mucositis during multicycle chemotherapy in patients with cancer: a randomized trial. Ann Intern Med 153:358-367

91. Valcarcel D, Sanz MA Jr, Sureda A, Sala M, Munoz L, Subira M, Laborda R, Clopes A, Sierra J (2002) Mouth-washings with recombinant human granulocyte-macrophage colony stimulating factor (rhGM-CSF) do not improve grade III-IV oropharyngeal mucositis $(\mathrm{OM})$ in patients with hematological malignancies undergoing stem cell transplantation. Results of a randomized double-blind placebocontrolled study Bone marrow transplantation 29:783-787

92. van der Lelie H, Thomas BL, van Oers RH, Ek-Post M, Sjamsoedin SA, van Dijk-Overtoom ML, Timmer JG, von dem Borne AE (2001) Effect of locally applied GM-CSF on oral mucositis after stem cell transplantation: a prospective placebo-controlled doubleblind study. Ann Hematol 80:150-154

93. Verhagen M, Wondergem M, Visser O (2009) Palifermin dose should be adjusted to different therapy regimens. Bone Marrow Transplant 43:665
94. Viens P, Gravis G, Bladou F, Lechevallier E, Baume D, Camerlo J, Cowen D, Coulange C, Serment G, Resbeut M, Maraninchi D (1996) Impact of recombinant human granulocyte colony stimulating factor on dose intensity and toxicity of three cycles of methotrexate, vinblastine, doxorubicin and cisplatin in patients with previously untreated urothelial bladder carcinoma. Eur Cytokine Netw 7:395-399

95. Vitale KM, Violago L, Cofnas P, Bishop J, Jin Z, Bhatia M, Kung AL, George D, Garvin J, Satwani P (2014) Impact of palifermin on incidence of oral mucositis and healthcare utilization in children undergoing autologous hematopoietic stem cell transplantation for malignant diseases. Pediatr Transplant 18:211-216

96. Wagner W, Alfrink M, Haus U, Matt J (1999) Treatment of irradiation-induced mucositis with growth factors (rhGM-CSF) in patients with head and neck cancer. Anticancer Res 19:799-803

97. Wang L, Huang X-E, Ji Z-Q, Liu M-Y, Qian T, Li L (2016) Safety and efficacy of a mouth-rinse with granulocyte colony stimulating factor in patients with chemotherapy-induced oral mucositis. Asian Pacific Journal of Cancer Prevention 17:413-418

98. Wu HG, Song SY, Kim YS, Oh YT, Lee CG, Keum KC, Ahn YC, Lee SW (2009) Therapeutic effect of recombinant human epidermal growth factor (RhEGF) on mucositis in patients undergoing radiotherapy, with or without chemotherapy, for head and neck cancer: a double-blind placebo-controlled prospective phase 2 multiinstitutional clinical trial. Cancer 115:3699-3708

Publisher's note Springer Nature remains neutral with regard to jurisdictional claims in published maps and institutional affiliations.

\section{Affiliations}

Richard M. Logan ${ }^{1}$ - Abdul Rahman Al-Azri ${ }^{1,2} \cdot$ Paolo Bossi $^{3} \cdot$ Andrea M. Stringer $^{4,5}$ • Jamie K. Joy ${ }^{6} \cdot$ Yoshihiko Soga $^{7}$. Vinisha Ranna ${ }^{8}$. Anusha Vaddi ${ }^{9,10}$ • Judith E. Raber-Durlacher ${ }^{11,12} \cdot$ Rajesh V. Lalla ${ }^{10} \cdot$ Karis Kin Fong Cheng $^{13}$. Sharon Elad ${ }^{9}$. On behalf of the Mucositis Study Group of the Multinational Association of Supportive Care in Cancer/ International Society of Oral Oncology (MASCC/ISOO)

1 Adelaide Dental School, Faculty of Health and Medical Sciences, The University of Adelaide, Adelaide 5005, South Australia, Australia

2 Dental and OMFS Department, Oral Pathology and Medicine, AlNahdha Hospital, Ministry of Health, Muscat, Oman

3 Medical Oncology, University of Brescia, ASST-Spedali Civili, Brescia, Italy

4 School of Pharmacy and Medical Sciences, University of South Australia, Adelaide, South Australia, Australia

5 Adelaide Medical School, Faculty of Health and Medical Sciences, The University of Adelaide, Adelaide 5005, South Australia, Australia

6 Clinical Pharmacy, Cancer Treatment Centers of America, Boca Raton, FL, USA
7 Okayama University Hospital, 2-5-1, Shikata-cho, Kita-ku, Okayama, Japan

8 Department of Oral and Maxillofacial Surgery, The Mount Sinai Hospital, New York, NY, USA

9 Oral Medicine, Eastman Institute for Oral Health, University of Rochester Medical Center, Rochester, NY, USA

10 Division of Oral and Maxillofacial Diagnostic Sciences, University of Connecticut School of Dental Medicine, Farmington, CT, USA

11 Department of Oral Medicine, Academic Centre for Dentistry Amsterdam, University of Amsterdam and Vrije Universiteit Amsterdam, Amsterdam, Netherlands

12 Department of Oral and Maxillofacial Surgery, Amsterdam UMC, University of Amsterdam, Amsterdam, Netherlands

13 Alice Lee Centre for Nursing Studies, Yong Loo Lin School of Medicine, National University of Singapore, Singapore, Singapore 